\title{
Moment - curvature behavior of basalt fibred concrete beams made with basalt fibre reinforced polymer bars
}

\author{
$V$ Saikrishna ${ }^{{ }^{*}}$, Srinivasa Reddy $\mathrm{V}^{2}, M V$ Seshagiri $\mathrm{Rao}^{3}$, and $S$ Shrihari ${ }^{4}$ \\ ${ }^{1}$ M. Tech (Structural Engineering), Department of Civil Engineering, GRIET, Hyderabad, India. \\ ${ }^{2}$ Professor of Civil Engineering, GRIET, Hyderabad, India. \\ ${ }^{3}$ Professor of Civil Engineering, CVR College of Engineering, Hyderabad, Telangana. \\ ${ }^{4}$ Professor of Civil Engineering, VJIT, Hyderabad, India.
}

\begin{abstract}
In the current study the moment - curvature behavior of basalt fibred concrete beams made with basalt fibre reinforced polymer bars and normal beams with steel rebars are evaluated. Basalt fibred reinforced concrete beams of M30 grade were casted with steel and BFRP rebars separately to study the flexural properties of basalt fibre and BFRP bars. From the load-deflection plots, flexural characteristics such as load at first crack, ultimate flexural strength, deflection at the centre and crack width at failure are evaluated. Deflections were measured at the central point and under the load using the deflection meters. The values of moments and curvatures are obtained. Moment curvature relationships are very important to assess out ductility of the structure and the amount of possible redistribution of stresses. The deformations measured are divided by the gauge length $(200 \mathrm{~mm})$ to obtain the strains at the particular level. From the top and bottom strains, the average curvatures were calculated. From these results, $M-\Phi$ diagrams are plotted.
\end{abstract}

\section{Introduction}

High temperature resistance, chemical stability, corrosion resistance, thermal conductivity, and insulation are all advantages of basalt fibre. Continuous basalt fibre can be used in a variety of ways. Because of its acid resistance, alkali resistance, high strength, high temperature resistance, low temperature resistance, smoothness, softness, scratchresistance, and insulation, it is not only used to make reinforced plastics for fibre reinforced cement and fibre reinforced plastic, but also to solve a variety of other problems. In concrete constructions, the use of fibre reinforced polymer tendons (FRP bars) as a replacement for steel bars is a viable option. This approach may be used to tackle the problem of concrete durability caused by steel bar corrosion, as well as satisfy the needs of specific constructions that require electromagnetic interference protection. Currently, civil engineering researchers are studying the performance of FRP bars and concrete structures reinforced with FRP bars, and this novel structure is extensively employed in coastal and subway engineering. FRP bars, on the other hand, have strong tensile strength, low elastic modulus, and linear deformation properties. These features cause brittle failure, greater fracture widths, and increased deflection, all of which have prevented FRP structures from being widely employed in civil engineering.

\section{Methodology}

Based on previous work by the authors, a basalt fibre length of $36 \mathrm{~mm}$ and a dose of 0.4 percent fibre volume of the concrete are considered for the investigation. According to IS 10262, the ratio of components in M30 grade concrete is 1: 1.85: 3.06. Steel rebars and basalt fibre reinforced polymer rebars are utilised in the beams in this investigation.

\section{Flexural behaviour of basalt fibre reinforced beams}

The number of cracks in under-reinforced beams rose as the load increased. There is give in steel after several cracking phases, thus the P-curve becomes more or less flat until the ultimate load is attained. As the load is increased further, the load drops, indicating fracture propagation. All of the beams broke due to concrete compression, and the load deformation curves were shown up to the point of failure.

${ }^{*}$ Corresponding author: saikrishna.vsk17@gmail.com 
To investigate the flexural characteristics of basalt fibre and BFRP bars, M30 grade basalt fibred reinforced concrete beams were formed with steel and BFRP rebars individually. Flexural parameters such as load at first crack, ultimate flexural strength, deflection at the centre, and crack width at failure are assessed using load-deflection plots. The deflection metres were used to measure the deflections at the central point and under the load. The moment and curvature values are calculated. Moment curvature relationships are critical for determining the structure's ductility and the amount of stress redistribution that can occur. The strains at each level are calculated by dividing the observed deformations by the gauge length $(200 \mathrm{~mm})$. The average curvatures of the top and bottom stresses were computed. Mdiagrams are created based on these finding

Table 1. Quantities per $\mathrm{m}^{3}$ of concrete for M30 grade concrete

\begin{tabular}{|c|c|c|c|c|}
\hline \multirow{2}{*}{ Concrete grade } & \multirow{2}{*}{ Cement $\left(\mathrm{Kg} / \mathrm{m}^{3}\right)$} & \multirow{2}{*}{ Water $(\mathrm{ltrs})$} & \multicolumn{2}{|c|}{ Aggregates } \\
\cline { 4 - 5 } & & & Fine $\left(\mathrm{kg} / \mathrm{m}^{3}\right)$ & Coarse $\left(\mathrm{kg} / \mathrm{m}^{3}\right)$ \\
\hline M30 & 372 & 186 & 687.6 & 1139 \\
\hline
\end{tabular}

Table 2. Flexure Test beam details

\begin{tabular}{|c|c|c|c|c|c|c|}
\hline $\begin{array}{l}\text { Beam } \\
\text { Section }\end{array}$ & $\begin{array}{l}\text { Grade of } \\
\text { Concrete }\end{array}$ & Beam type & $\begin{array}{c}\text { Tension } \\
\text { Reinforcement }\end{array}$ & $\begin{array}{c}\text { Nominal } \\
\text { Compression } \\
\text { Reinforcement }\end{array}$ & $\begin{array}{c}\text { Shear } \\
\text { Reinforcement }\end{array}$ & $\begin{array}{c}\text { Beam } \\
\text { dimensions }\end{array}$ \\
\hline \multirow[t]{2}{*}{$\begin{array}{l}\text { Under } \\
\text { reinforced }\end{array}$} & \multirow[t]{2}{*}{ M30 } & $\begin{array}{c}\text { Conventional } \\
\text { Concrete } \\
\text { Beam }\end{array}$ & $\begin{array}{c}2 \text { Nos - } \\
10 \mathrm{~mm} \varphi \\
\text { Fe } 415 \text { steel } \\
\text { bars }\end{array}$ & $\begin{array}{c}2 \text { Nos }-8 \mathrm{~mm} \varphi \\
\text { Steel bars }\end{array}$ & $\begin{array}{c}2 \text { legged - } \\
8 \mathrm{~mm} \varphi \text { Steel } \\
\text { @ } 100 \mathrm{~mm} \mathrm{c/c}\end{array}$ & $\begin{array}{l}100 \mathrm{~mm} \mathrm{x} \\
150 \mathrm{~mm} \mathrm{x} \\
1100 \mathrm{~mm}\end{array}$ \\
\hline & & $\begin{array}{c}\text { BFRP } \\
\text { Concrete } \\
\text { Beam }\end{array}$ & $\begin{array}{c}2 \text { Nos - } \\
10 \mathrm{~mm} \varphi \\
\text { BFRP bars }\end{array}$ & $\begin{array}{c}2 \text { Nos }-8 \mathrm{~mm} \varphi \\
\text { Steel bars }\end{array}$ & $\begin{array}{c}2 \text { legged - } \\
8 \mathrm{~mm} \varphi \text { Steel } \\
@ 100 \mathrm{~mm} \mathrm{c} / \mathrm{c}\end{array}$ & $\begin{array}{l}100 \mathrm{~mm} \mathrm{x} \\
150 \mathrm{~mm} \mathrm{x} \\
1100 \mathrm{~mm}\end{array}$ \\
\hline
\end{tabular}
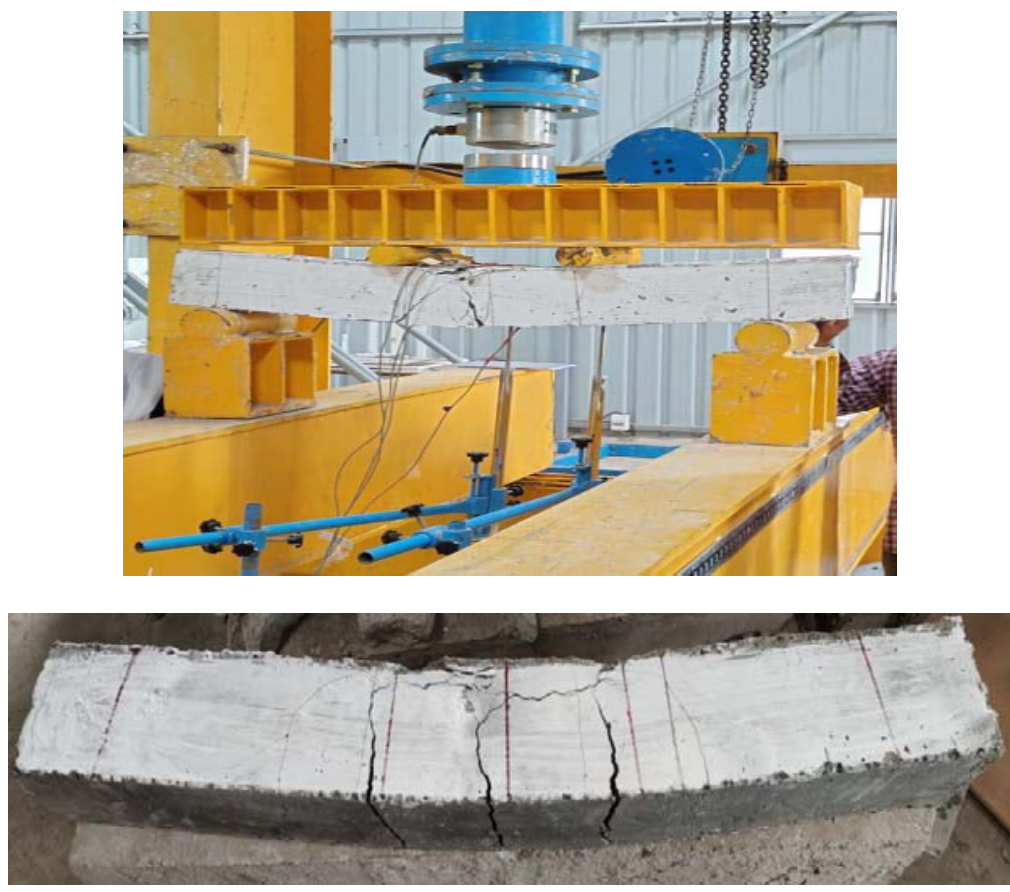

Fig.1. Flexural testing of M30 grade basalt fibred concrete made with BFRP bars 
Table 3. Flexural load capacities and deflections of BFRP and conventional steel beams

\begin{tabular}{|c|c|c|}
\hline Property & Steel reinforced concrete beam & Basalt reinforced concrete beam \\
\hline Load at First Crack & $13.3 \mathrm{kN}$ & $28.8 \mathrm{kN}$ \\
\hline Maximum Load Capacity, F & $38.6 \mathrm{kN}$ & $47.7 \mathrm{kN}$ \\
\hline Moment Carrying Capacity, M & $9.52 \mathrm{kN} . \mathrm{m}$ & $11.23 \mathrm{kN} . \mathrm{m}$ \\
\hline Deflection at Mid-span, D & $5.7 \mathrm{~mm}$ & $15 \mathrm{~mm}$ \\
\hline Crack Width at failure & $1 \mathrm{~mm}$ & $5 \mathrm{~mm}$ \\
\hline
\end{tabular}

Table 4. M- $\varnothing$ values of M30 grade basalt fibred concrete beams made with basalt fibre reinforced polymer (BFRP) bars

\begin{tabular}{|c|c|c|c|c|c|c|c|}
\hline \multicolumn{2}{|c|}{ Beam 1} & \multicolumn{2}{|c|}{ Beam 2} & \multicolumn{2}{|c|}{ Beam 3} & \multicolumn{2}{|c|}{ Beam 4} \\
\hline \multicolumn{2}{|c|}{$\begin{aligned} & \text { No fibre } \\
+ & \text { Steel rebars }\end{aligned}$} & \multicolumn{2}{|c|}{$\begin{array}{l}\text { Basalt fibre } \\
+ \text { Steel rebars }\end{array}$} & \multicolumn{2}{|c|}{$\begin{array}{c}\text { No fibre } \\
+ \text { BFRP rebars }\end{array}$} & \multicolumn{2}{|c|}{$\begin{aligned} & \text { Basalt fibre } \\
+ & \text { BFRP rebars }\end{aligned}$} \\
\hline $\mathrm{M} \mathrm{kN-m}$ & $\Phi$ & $\mathrm{M} k \mathrm{kN}-\mathrm{m}$ & $\Phi$ & $\mathrm{M} \mathrm{kN-m}$ & $\Phi$ & $\mathrm{M} \mathrm{kN-m}$ & $\Phi$ \\
\hline 0 & 0 & 0 & 0 & 0 & 0 & 0 & 0 \\
\hline 0.83 & 7.39E-07 & 0.83 & $7.78 \mathrm{E}-07$ & 0.83 & $8.02 \mathrm{E}-07$ & 0.83 & $1.01 \mathrm{E}-06$ \\
\hline 1.67 & 7.39E-07 & 1.67 & $7.78 \mathrm{E}-07$ & 1.67 & $8.02 \mathrm{E}-07$ & 1.67 & $1.21 \mathrm{E}-06$ \\
\hline 2.50 & $1.47 \mathrm{E}-06$ & 2.50 & $1.55 \mathrm{E}-06$ & 2.50 & $1.6 \mathrm{E}-06$ & 2.50 & $2.02 \mathrm{E}-06$ \\
\hline 3.33 & $2.22 \mathrm{E}-06$ & 3.33 & $2.34 \mathrm{E}-06$ & 3.33 & $2.41 \mathrm{E}-06$ & 3.33 & $2.83 \mathrm{E}-06$ \\
\hline 4.17 & $2.96 \mathrm{E}-06$ & 4.17 & $3.11 \mathrm{E}-06$ & 4.17 & $3.21 \mathrm{E}-06$ & 4.17 & $3.63 \mathrm{E}-06$ \\
\hline 5.00 & $3.70 \mathrm{E}-06$ & 5.00 & $3.89 \mathrm{E}-06$ & 5.00 & $4.01 \mathrm{E}-06$ & 5.00 & $4.43 \mathrm{E}-06$ \\
\hline 5.83 & $4.06 \mathrm{E}-06$ & 5.83 & $4.28 \mathrm{E}-06$ & 5.83 & $4.41 \mathrm{E}-06$ & 5.83 & $5.04 \mathrm{E}-06$ \\
\hline 6.67 & $4.81 \mathrm{E}-06$ & 6.67 & $5.06 \mathrm{E}-06$ & 6.67 & $5.22 \mathrm{E}-06$ & 6.67 & $5.85 \mathrm{E}-06$ \\
\hline 7.50 & $5.55 \mathrm{E}-06$ & 7.50 & $5.84 \mathrm{E}-06$ & 7.50 & $6.02 \mathrm{E}-06$ & 7.50 & $6.65 \mathrm{E}-06$ \\
\hline 8.33 & $6.28 \mathrm{E}-06$ & 8.33 & $6.62 \mathrm{E}-06$ & 8.33 & $6.82 \mathrm{E}-06$ & 8.33 & $7.46 \mathrm{E}-06$ \\
\hline 9.17 & $7.02 \mathrm{E}-06$ & 9.17 & $7.39 \mathrm{E}-06$ & 9.17 & $7.62 \mathrm{E}-06$ & 9.17 & $8.26 \mathrm{E}-06$ \\
\hline 10.00 & $7.77 \mathrm{E}-06$ & 10.00 & $8.18 \mathrm{E}-06$ & 10.00 & $8.43 \mathrm{E}-06$ & 10.00 & $9.67 \mathrm{E}-06$ \\
\hline 10.83 & $9.22 \mathrm{E}-06$ & 10.83 & $9.70 \mathrm{E}-06$ & 10.83 & $1 \mathrm{E}-05$ & 10.83 & $1.09 \mathrm{E}-05$ \\
\hline \multirow[t]{3}{*}{11.00} & $9.95 \mathrm{E}-06$ & 11.00 & $1.05 \mathrm{E}-05$ & 11.67 & $1.08 \mathrm{E}-05$ & 11.67 & $1.17 \mathrm{E}-05$ \\
\hline & & & & 12.17 & $1.16 \mathrm{E}-05$ & 12.50 & $1.25 \mathrm{E}-05$ \\
\hline & & & & & & 13.00 & $1.33 \mathrm{E}-05$ \\
\hline
\end{tabular}

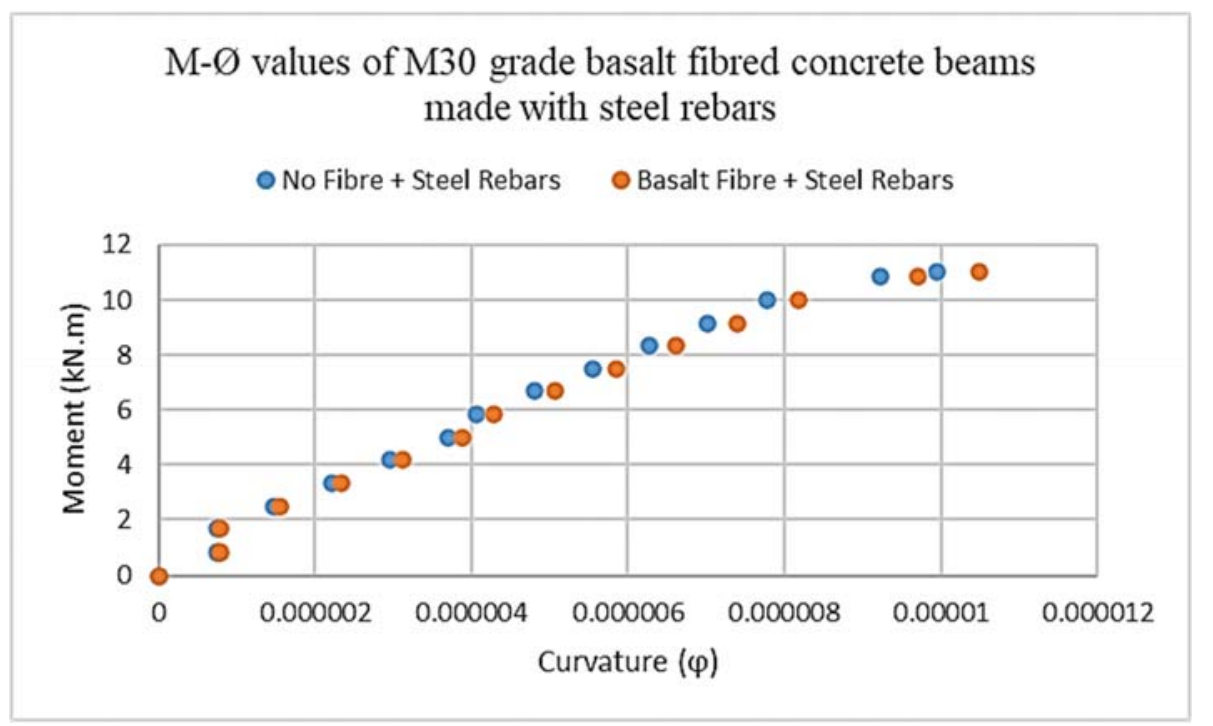

Fig.1. M- $\varnothing$ plot of with and without basalt fibred M30 grade reinforced concrete beams made with steel rebars 


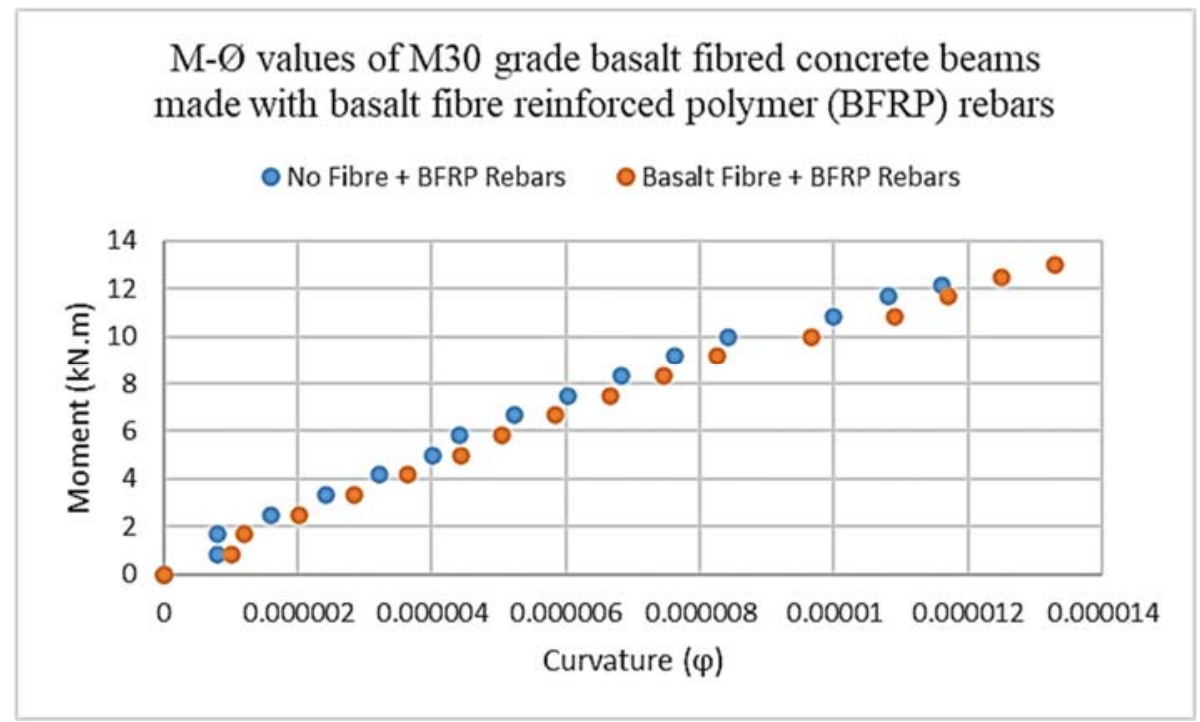

Fig.2. M- $\varnothing$ plot of with and without basalt fibred M30 grade reinforced concrete beams made with basalt fibre reinforced polymer (BFRP) rebars

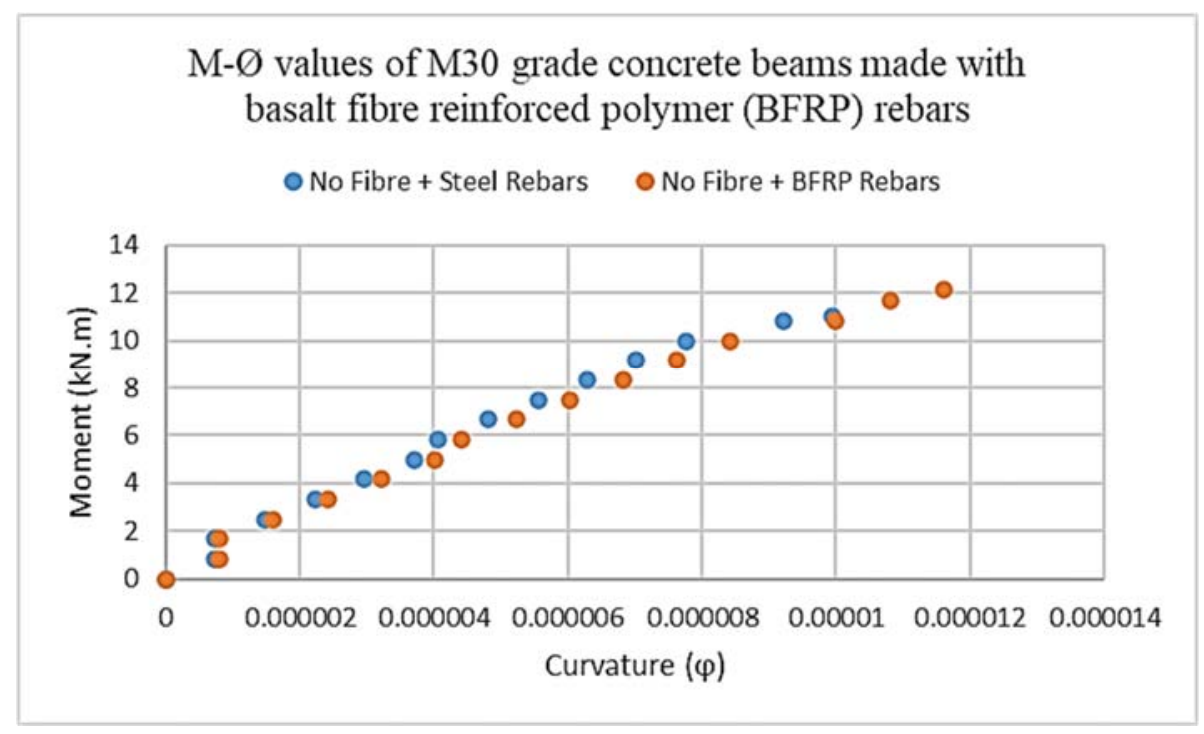

Fig.3. M- $\varnothing$ plot of non-fibrous M30 grade reinforced concrete beams made with steel and basalt fibre reinforced polymer (BFRP) rebars 


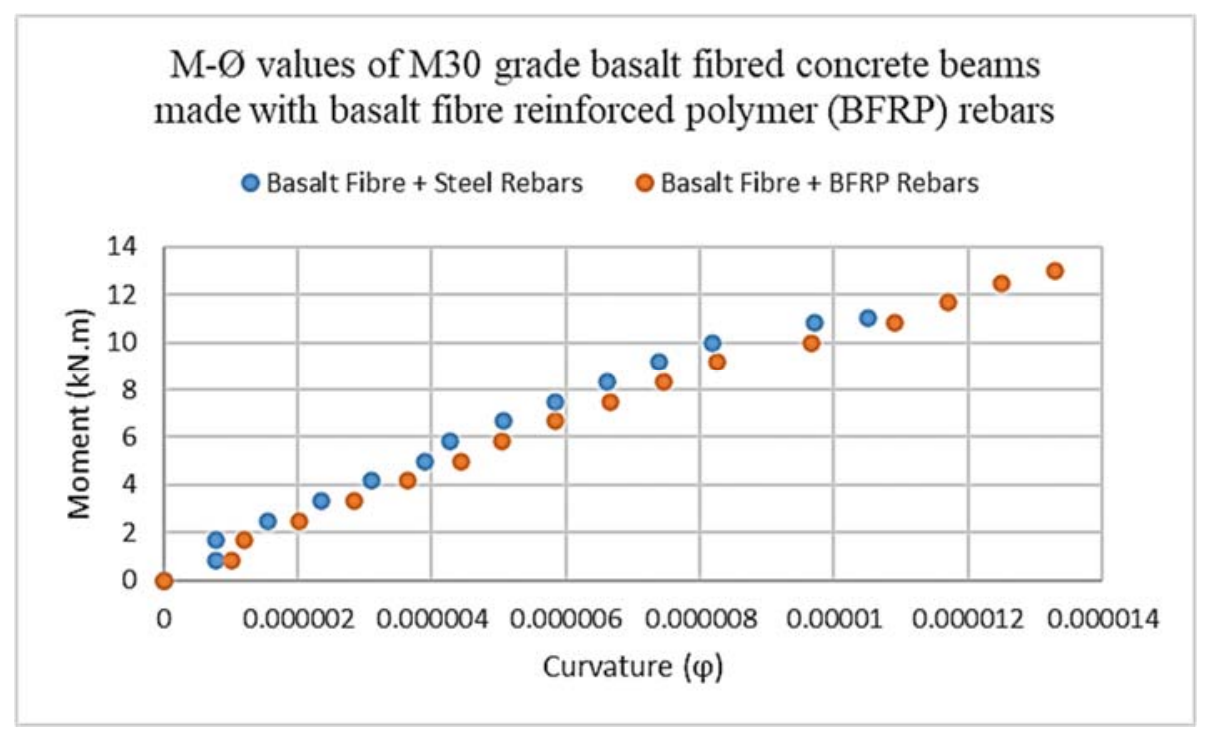

Fig.4. M- $\varnothing$ plot of basalt fibred M30 grade reinforced concrete beams made with steel and basalt fibre reinforced polymer (BFRP) rebars

These moment curvature plots for under reinforced basalt fibred M30 grade reinforced concrete beams built with basalt fibre reinforced polymer (BFRP) rebars showed a similar pattern to load deflection plots for reinforced concrete beams made with steel rebars. Curvature grows steadily with increasing moment in beams until numerous breaking stages are reached, at which point it increases dramatically with constant moment or with slight variations in the moment. Until the ultimate moment, the M-curve becomes more or less flat. Finally, all of the beams collapsed due to concrete compression, and the moment curvature plots were produced up to the point of failure. Visible flexural fractures occurred at 70 percent to 80 percent of the ultimate load of each beam in conventional concrete beams built with steel rebars, and at 75 percent to 85 percent of the ultimate load of each beam in beams made with BFRP rebars. The fracture began to expand significantly, suggesting higher steel stresses than the yield strain. Tension failure, also known as ductile failure, was seen in all of the beams. There is a lot of swelling along with the cracks. Cracks spread towards the top of the beam when the weight was raised further. The fissures got more apparent when the beams were forced to bend more, and the concrete was crushed at one or both ends. The load reduced as the beam deflection increased, which was accompanied by concrete spalling. All basalt fibred M30 grade reinforced concrete beams constructed with steel and basalt fibre reinforced polymer (BFRP) rebars exhibit the same crack pattern. Deflections at service loads are less than the maximum allowed deflection of $4.8 \mathrm{~mm}$, i.e. Span/250, prescribed by IS $456-2000$ in basalt fibred M30 grade reinforced concrete beams constructed with steel and basalt fibre reinforced polymer (BFRP) rebars. As a result, the usage of steel and basalt fibre reinforced polymer (BFRP) rebars does not contradict the codes of practice's serviceability requirements. Except for the increased values of loads at ultimate and at first crack in basalt fibred M30 grade reinforced concrete beams made with basalt fibre reinforced polymer (BFRP) rebars, the load deflection and moment -distribution behaviour of basalt fibred M30 grade reinforced concrete beams made with steel and basalt fibre reinforced polymer (BFRP) rebars is observed to be similar. Curvature rose progressively in under-reinforced beams as the moment increased, up to numerous breaking stages and beyond, and subsequently curvature increased dramatically at constant moment or with slight variations in the moment. Until the final moment is achieved, the Mcurve is more or less flat. Because all of the beams broke due to concrete compression, moment curvature graphs were generated up to the point of failure. All under-reinforced beams built with BFRP bars behave in the same way. The rise in the horizontal plateau of the moment-curvature plots and the increase in ultimate moment in reinforced beams produced with BFRP bars than in regular beams constructed with steel rebars are the variations noted in the momentcurvature behaviour of BFRP rebar beams.

The moment curvature plots for BFRP-reinforced beams were found to follow a similar pattern to the load deflection plots of beams. Curvature rose progressively in under-reinforced beams as the moment increased, up to numerous breaking stages and beyond, and subsequently curvature increased dramatically at constant moment or with slight variations in the moment. Because all of the beams broke due to concrete compression, moment curvature graphs were generated up to the point of failure. The rise in the plateau of the moment-curvature plots and the increase in ultimate moment in reinforced beams produced with BFRP bars than in regular beams with steel rebars are the variations detected in the moment- 
curvature behaviour of reinforced beams manufactured with BFRP bars. The rise in the plateau of the moment-curvature plots and the increase in ultimate moment in beams with BFRP bars and basalt fibre than in normal beams with steel rebars are the variations detected in the moment-curvature behaviour of copper slag based reinforced concrete beams.

\section{Conclusions}

1. Visible flexural fractures occurred at 70 percent to 80 percent of the ultimate load of each beam in conventional concrete beams built with steel rebars, and at 75 percent to 85 percent of the ultimate load of each beam in beams made with BFRP rebars..

2. Deflections at service loads are less than the maximum allowed deflection of $4.8 \mathrm{~mm}$, i.e. Span/250, prescribed by IS $456-2000$ in basalt fibred M30 grade reinforced concrete beams constructed with steel and basalt fibre reinforced polymer (BFRP) rebars. As a result, the usage of steel and basalt fibre reinforced polymer (BFRP) rebars does not contradict the codes of practice's serviceability requirements.

3. Except for the increased values of loads at ultimate and at first crack in basalt fibred M30 grade reinforced concrete beams made with basalt fibre reinforced polymer (BFRP) rebars, the load deflection and moment -distribution behaviour of basalt fibred M30 grade reinforced concrete beams made with steel and basalt fibre reinforced polymer (BFRP) rebars is observed to be similar.

4. The rise in the plateau of the moment-curvature plots and the increase in ultimate moment in reinforced beams produced with BFRP bars than in regular beams with steel rebars are the variations detected in the moment-curvature behaviour of reinforced beams manufactured with BFRP bars. The rise in the plateau of the moment-curvature plots and the increase in ultimate moment in beams with BFRP bars and basalt fibre than in normal beams with steel rebars are the variations detected in the momentcurvature behaviour of copper slag based reinforced concrete beams.

\section{References}

1. Srinivas. T, Abhignya. G and Ramana Rao. N.V, A Review on Geopolymer RCC Beams made with Recycled Coarse Aggregate, E3S Web of Conferences, ICMED, 10-12 July 2020, India (2020).

2. B. J. Varghese, P. B. Bobba and M. Kavitha, 2016 IEEE 7th Power India International Conference (PIICON), 2016, pp. 1-6
3. T. Srinivas, S. V. Srinidhi and N.V. Ramana Rao, A Review on Flexural Behavior of RCC Beams Made with Geopolymer Concrete, E3S Web of Conferences, ICMED, 10-12 July 2020, India (2020).

4. T. Srinivas, P. Bhavana, and N. V. Ramana Rao, Effect of Manufactured Sand on Flexural Behavior of Geopolymer RCC Beams: A review, E3S Web of Conferences, ICMED, 1012 July 2020, India (2020).

5. T. Srinivas and N.V.Ramana Rao, IJCIET, Volume 10, 510 (2019).

6. K. Sai Gopi, Dr. T. Srinivas and S. P. Raju V, E3S Web of Conferences ICMED 184, 01084GRIET, 28-29 February, https://doi.org/10.1051/e3sconf/2020184011084 (2020)

7. Jagannadha Kumar, M.V., Jagannadha Rao, K., Dean Kumar, B., Srinivasa Reddy, V., Int. J. of Civil Eng. and Tech., 9(7), pp. 1133-1141 (2018)

8. Ganta, J.K., Seshagiri Rao, M.V., Mousavi, S.S., Srinivasa Reddy, V., Bhojaraju, C., Structures 28, pp. 956-972 (2020)

9. K. Satyanarayana, A. V. Gopal, and P.B. Babu, Proceedings of the Institution of Mechanical Engineers, Part C: Journal of Mechanical Engineering Science, 228(1), 152 (2014)

10. Naidu, K.S.S.T., Rao, M.V.S., Reddy, V.S., Int. J. of Innov. Tech. and Explor. Eng.g (IJITEE), 8(9 Special Issue 2), pp. 641-642 (2019)

11. Kavitha, Merugu; Prasad, Dinkar; Bobba, Phaneendra Babu: IET Electric Power Applications, 2019, 13, (8), p. 1184-1192

12. Chandana Priya, C., Seshagiri Rao, M.V., Srinivasa Reddy, V., Int. J. of Civil Eng. and Tech., 9(11), pp. 2218-2225 (2018)

13. Satya Sai Trimurty Naidu, K., Seshagiri Rao, M.V., Srinivasa Reddy, V., Int. J. of Civil Eng. and Tech., 9(11), pp. 2383-2393 (2018)

14. Supriya, Y., Srinivasa Reddy, V., Seshagiri Rao, M.V., Shrihari, S., Int. J. of Rec. Tech. and Engi., 8(3), pp. 5381-5385 (2019)

15. Kotkunde, N., Krishna, G., Shenoy, S.K., Gupta, A.K., Singh, S.K. International Journal of Material Forming, 10 (2), pp. 255-266 (2017)

16. Govardhan, D., Kumar, A.C.S., Murti, K.G.K., Madhusudhan Reddy, G. Materials and Design, 36, pp. 206-214. (2012)

17. Kumar, P., Singhal, A., Mehta, S., Mittal, A. Journal of Real-Time Image Processing, 11 (1), pp. 93-109. (2016)

18. Raghunadha Reddy, T., Vishnu Vardhan, B., Vijayapal Reddy, P. International Journal of Applied Engineering Research, 11 (5), pp. 3092$3102(2016)$

19. B. T. P. Singh, B. P. Babu and Y. Satyavani, 2019 IEEE Transportation Electrification Conference (ITEC-India), 2019, pp. 1-6

20. Hussaini, S.M., Krishna, G., Gupta, A.K., Singh, S.K. Journal of Manufacturing Processes, 18, pp. 
$151-158(2015)$ 